\title{
Fire regime effects on annual grass seeds as food for threatened grass-finch
}

Anna Weier ${ }^{1}$, lan J. Radford ${ }^{2 *}$, Leigh-Ann Woolley ${ }^{3}$ and Michael J. Lawes ${ }^{4}$

\begin{abstract}
Background: The Gouldian finch (Erythrura gouldiae, Gould 1844) is a threatened grass finch (Estrildidae) endemic to the tropical savannas of northern Australia. Current fire regimes, consisting of frequent and extensive fire across these savanna grasslands, affect the type and availability of grass seed for granivores. Gouldian finches are particularly affected as they feed exclusively on grass seed and, unlike other finches, do not supplement their own or their hatchlings' diet with other protein sources. Annual Sorghum spp. provides the main source of seed to Gouldian finches throughout the monsoonal dry season and concurrent breeding season, making it a critical resource throughout breeding habitat. This study examined the effects of fire regimes, including fire frequency, time since the last fire, seasonality of fire on plant density, seed production, and overall seed abundance of the annual grass Sorghum stipoideum (Ewart \& White) C.A. Gardn. \& C.E. Hubb. Monitoring of S. stipoideum took place across Gouldian finch breeding habitat over three consecutive years and these measures were used in conjunction with local fire history at these sites to test for effects of fire attributes on Sorghum spp. seed ecology.

Results: We found that seasonality of fire had the greatest impact on S. stipoideum plant density and overall seed abundance, with early dry season fires resulting in $25 \%$ higher plant and seed density compared to late dry season fires. Seed production per plant peaked at three years post fire but then declined. There was no significant influence of fire frequency in the analysis.

Conclusions: Although fire effects were detected, these were muted within current fire regimes experienced in the region, and it is unlikely that appreciable impacts would occur on S. stipoideum seed availability to Gouldian finches while breeding. However, reduced seed density resulting from repeated high intensity fires could lead to exacerbation of food shortages postulated for Gouldian finches in the late dry season, as seeds naturally become scarce at the soil surface where finches forage. Early dry season fires maximize Sorghum spp. seed abundance. These findings support the implementation of low intensity early dry season burning to promote optimal food and breeding resources for threatened finches.
\end{abstract}

Keywords: Erythrura gouldiae, fire ecology, food limitation, Gouldian finch, Kimberley, savanna, Sorghum stipoideum

\footnotetext{
* Correspondence: ian.radford@dbca.wa.gov.au

${ }^{2}$ Department of Biodiversity, Conservation and Attractions, Lot 248 Ivanhoe

Road, Kununurra, Western Australia 6743, Australia

Full list of author information is available at the end of the article
} 


\section{Resumen}

Antecedentes: El pinzón de Gould (Erythrura gouldiae, Gould 1844) es un ave paseriforme (Estrildidae), catalogada como amenazada, endémica de las sabanas graminosas tropicales del norte de Australia. Los regímenes de incendios corrientes, consistentes en fuegos frecuentes y extensivos a través de estos pastizales de sabana, afectan el tipo y disponibilidad de semillas de pastos para granívoros. Los pinzones de Gould son particularmente afectados dado que se alimentan exclusivamente de semillas de pastos y, a diferencia de otros pájaros pinzones, no suplementan su dieta o la de sus crías con otras fuentes de proteínas. Los sorgos anuales (Sorghum spp.) proveen la principal fuente de semilla para los pinzones de Gould durante la estación seca de monzones y su concurrente estación de cría, haciendo del mismo un recurso crítico en el hábitat de cría. Este estudio examinó los efectos de los regímenes de fuegos, incluyendo las frecuencias, el tiempo desde el último incendio, la estacionalidad el fuego sobre la densidad de plantas, la producción de semillas y sobre todo la abundancia de semillas del sorgo anual Sorghum stipoideum (Ewart \& White) C.A. Gardn. \& C.E. Hubb. El monitoreo del S. stipoideum tuvo lugar en el hábitat de anidamiento del pinzón de Gould por tres años consecutivos, y esas medidas fueron usadas en conjunto con la historia de fuego local en esos sitios para probar los efectos de los atributos del fuego en la ecología de las semillas de sorgo.

Resultados: Encontramos que la estacionalidad de los incendios tuvo el mayor impacto sobre la densidad de plantas de S. stipoideum, y sobre todo en la densidad de semillas, y que los fuegos tempranos en la estación seca resultaron en un $25 \%$ más de densidad de plantas y semillas comparadas con fuegos ocurridos durante la temporada seca tardía. La producción de semillas por planta tuvo un pico máximo tres años post fuego y luego declinó. No hubo en el análisis una influencia significativa de la frecuencia del fuego.

Conclusiones: Aunque se detectaron efectos del fuego, éstos pasaron desapercibidos dentro los actuales regímenes de fuegos experimentados en la región, y es improbable que puedan ocurrir impactos significativos en la disponibilidad de semillas de S. stipoideum para el pinzón de Gould mientras esté procreando. Sin embargo, una reducción en la densidad de semillas resultante de fuegos repetidos de alta intensidad, pueden llevar a una exacerbación en la reducción de alimento para el pinzón de Gould en la estación seca tardía, dado que las semillas resultan escasas en la superficie del suelo donde forrajean estos pinzones. Los fuegos que ocurren en la estación seca temprana maximizan la abundancia de semillas de Sorghum spp. Estos hallazgos apoyan la implementación de quemas prescriptas durante la estación seca temprana para proveer recursos alimenticios y de crianza óptimos para los pinzones amenazados.

\section{Introduction}

Current fire regimes in northern Australian savannas are suboptimal for many bird species, especially granivorous species including the grass finches (Reside et al. 2012, Woinarski and Legge 2013). The Gouldian finch (Erythrura gouldiae, Gould 1844), a threatened grass finch (Estrildidae; Department of the Environment 2016) is endemic to the tropical savannas of northern Australia (Blakers et al. 1984). Like most grass finches, the Gouldian finch feeds on seed from both annual and perennial grasses, and tracks these seeds as they become available across both breeding and non-breeding habitats (Tidemann 1996, Dostine et al. 2001). Fire regimes are purported to affect the type (annual versus perennial) and the availability of grass seed for granivores in tropical savannas. In general, seeds of annual grass species are available during the tropical dry season when most grass finches breed, including the Gouldian finch (Brazill-Boast et al. 2011), while perennial grass seeds are available mainly during the monsoonal wet season (Dostine and Franklin 2002, Lewis 2007). Gouldian finches may be subject to perennial grass seed limitation in the monsoonal season under some fire regime scenarios due to increasing spatial and temporal scarcity (Crowley and Garnett 1999, Dostine et al. 2001, Legge et al. 2015), although this is yet to be fully elucidated. Paradoxically, abundant annual grasses may also be a limiting factor for Gouldian finches under some fire regimes. Recent studies have suggested that Gouldian finch breeding success is related to fire regimes that promote production of annual Sorghum spp. seeds of higher nutritional quality (Weier et al. 2016, 2017). Conversely, it is known that nutritional stress can delay breeding, resulting in fewer, smaller offspring (Pryke et al. 2012). Increases in Gouldian finches stress levels under some fire regimes (Legge et al. 2015) may therefore be related to Sorghum spp. seed quality and nutritional stress in finches under some fire regime scenarios. Although previous studies have investigated annual Sorghum spp. grass populations and seed set responses to northern Australian savanna fire regimes (Mott and Andrew 1985, Watkinson et al. 1989, Scott et al. 2010), little is known of the effects of fire regime on annual seed availability in situ with breeding Gouldian finches.

Breeding Gouldian finches feed exclusively on grass seed and, unlike other grass finch species, they do not 
supplement their own diets or their hatchlings' diets with other protein sources such as insects (Tidemann 1993, 1996; Dostine and Franklin 2002). Breeding Gouldian finches are entirely dependent on the seeds of the dominant annual grass species during the dry season, especially Sorghum spp. (Tidemann 1996, Dostine and Franklin 2002). Thus, annual Sorghum spp. grass seed availability is an important criterion in breeding habitat selection by Gouldian finches (and other grass finch species) in northern Australia (Dostine et al. 2001, Brazill-Boast et al. 2011, Weier et al. 2016, Weier et al. 2017). Weier et al. (2016) and Weier et al. (2017) found that the most successful finch breeding occurred at recently but infrequently burned sites where Sorghum spp. seeds had greater nutritional quality. This study seeks to understand whether absolute shortages of annual Sorghum spp. seed are likely under local fire regimes in known Gouldian finch breeding habitat. Fire regimes in some savanna contexts have reduced annual Sorghum spp. plant density and seed production (Mott and Andrew 1985, Watkinson et al. 1989, Lonsdale et al. 1998, Scott et al. 2010); these reductions may affect Gouldian finches if they also occur in breeding habitats.

In addition to promoting annual Sorghum spp. grass dominance (Russell-Smith et al. 2003), frequent fires may affect Sorghum spp. density and seed availability. Sorghum spp. generally increase in relative abundance with regular burning because (1) unlike perennial grass species, annual grasses can grow, mature, and reproduce within the short intervals between frequent fires; and (2) regular fires reduce competition from shrubs, trees, and perennial grasses (Russell-Smith et al. 2002, RussellSmith et al. 2003). However, annual dry season fires may reduce Sorghum spp. grass density, as fire can kill Sorghum spp. seeds (up to 38\% in some cases) in the seed bank on the soil surface (Mott and Andrew 1985). These reductions are most likely following high intensity late dry season fires (Watkinson et al. 1989), but many Sorghum spp. seeds also survive fires due to their self-burial mechanism (Andrew and Mott 1983). In contrast, long-term exclusion of fires or long inter-fire intervals $(>8 \mathrm{yr})$ has the potential to severely reduce Sorghum spp. biomass and seed abundance as vegetation shifts towards woody plant species dominance (Russell-Smith et al. 2003, Woinarski et al. 2004, Radford and Fairman 2015). These reductions may be attributed to barrier effects of dense leaf litter, which would be removed by more frequent fire (Andrew and Mott 1983, Scott et al. 2010). Thus, both very frequent and very infrequent fires may affect seed availability to granivores by reducing annual grass and seed density.

In addition to fire frequency, other fire regimes attributes, such as season and fire severity, may affect Sorghum spp. population density and seed abundance at
Gouldian finch breeding sites. Fire severity is largely driven by seasonality (Liedloff et al. 2001). Vegetation (especially grass) becomes highly flammable as it dries during each dry season (Felderhof and Gillieson 2006). Because the herb and grass layer holds moisture from the preceding wet season (Lewis 2007), early dry season fires tend to be less intense than those later in dry season. Late dry season fires are more intense because air temperatures are higher, grass fuel is fully cured, humidity is low, and fuel biomass is at its peak (Woinarski $e t$ al. 2007). Intense late dry season fires are likely to kill a greater proportion of the seed bank on the soil surface than early dry season fires, leading to lower plant density in the following Gouldian finch breeding season. It is unknown if this reduction is sufficient to affect seed resources for finches. Early wet season burns may have the greatest effect on Sorghum spp. populations (Lonsdale et al. 1998); these fires occur after Sorghum spp. seed germination, but before seed set, and can kill growing Sorghum spp. plants, thereby severely reducing plant density and seed set. Early wet season burning may dramatically reduce Sorghum spp. population density for several years, as this annual species does not appear to have a persistent inter-annual seed bank, so Sorghum spp. may have to recolonize wet season burned areas (Andrew and Mott 1983). Thus, early wet season burns have the potential to destroy local annual grass populations in the short and medium term; if these fires are extensive enough, they may cause finches to abandon breeding.

Indirect effects of fire on Sorghum spp. fecundity and density may reduce or increase the availability of seed supporting breeding Gouldian finches. Fire can reduce density of Sorghum spp. plants due to fire related seed mortality (Scott et al. 2010). However, reduced competition and density of both Sorghum spp. and other herbaceous plants after fire has also been found to increase fecundity in annual Sorghum intrans F.Muell. ex Benth. plants (Andrew 1986a). Increased seed production per plant may to some extent compensate for reduced plant density after some fires. Fire can affect available nutrients for Sorghum spp. plants (Weier et al. 2017), which potentially affects seed production. Nutrients can be either lost after fire through volatilization (nitrogen and sulphur), or gained after fire through mineralization and nitrogen fixation, depending on fire frequency and intensity (Gibson 2009). Plants have limited resources that must be distributed among growth, maintenance, and reproduction (Silvertown and Charlesworth 2001). Sorghum spp. growth and fecundity can therefore be influenced by fire related nutrient flux at Gouldian finch breeding sites (Gibson 2009).

Although annual Sorghum spp. has putatively increased in abundance across the northern Australian landscape due to contemporary fire regimes (Scott et al. 
2009), it is important to understand what combination of fire season and frequency leads to optimal Sorghum spp. seed production for breeding Gouldian finches. It is also important to understand if fire regimes outside this optimal range can cause severe enough reduction in seed set to impact breeding finches. Determining the effect of fire on the availability of annual grass seed during the dry season is integral to informing fire management practices for conserving threatened breeding grass finches and many other granivorous species in tropical savannas. This study examines the effect of fire, including fire frequency, time since the last fire, and the seasonal timing of fire, on the density and fecundity of Sorghum stipoideum (Ewart \& White) C.A. Gardn. \& C.E. Hubb at Gouldian finch breeding sites in the east Kimberley, Western Australia. We hypothesize that very frequent fires (e.g., $>1$ fire every $2 \mathrm{yr}$; Russell-Smith et al. 2013) will reduce the density of Sorghum spp. plants and abundance of seeds available to breeding Gouldian finches (Mott and Andrew 1985). We predict that early dry season fires will result in greater seed and plant density than high intensity late dry season fires due to partial loss of seed banks (Scott et al. 2010). We predict that seed production density will increase with increasing time since fire up to a certain threshold, then decline (Russell-Smith et al. 2003). Based on the abundance of annual Sorghum spp. at Gouldian finch breeding sites (Brazill-Boast et al. 2011), we also predict that seed density will be sufficient under most current fire regimes for breeding birds foraging for grass seeds.

\section{Methods}

\section{Study sites}

Study sites were located within a $30 \mathrm{~km}$ radius of the town of Wyndham $\left(15^{\circ} 34^{\prime} \mathrm{S}, 128^{\circ} 09^{\prime} \mathrm{E}\right)$, in the east Kimberley region of Western Australia (Fig. 1). Annual rainfall at Wyndham in the three wet seasons of this study (2013 through 2015) was $768 \mathrm{~mm}, 1257 \mathrm{~mm}$, and $656 \mathrm{~mm}$, respectively (Wyndham; Australian Bureau of Meteorology 2016, http://www.bom.gov.au). Most rain falls in the monsoonal wet season, which begins in December and continues through March. The mean maximum daily temperatures during field season were $37 \pm 0.3{ }^{\circ} \mathrm{C}, 37 \pm 0.8{ }^{\circ} \mathrm{C}$, and $38 \pm$ $0.6{ }^{\circ} \mathrm{C}$, respectively. The field sites were typical Gouldian finch breeding habitat (savanna grassland) where the topography is gently sloping $\left(\sim 15^{\circ}\right)$ rocky sandstone ridges. The overstory is dominated by Corymbia dichromophloia (F.Muell.) K.D.Hill \& L.A.S.Johnson and Eucalyptus miniata A.Cunn. ex Schauer with an understory dominated by the annual grass Sorghum stipoideum and sub-dominated by the perennial grass Triodia bitextura Lazarides (BrazillBoast et al. 2013). During this study, each of the study sites (excluding the Bastion study site) were active breeding sites for Gouldian finches (Fig. 1).

\section{Fire history}

Fire history, including fire frequency (the number of years burned out of a total of sixteen), time since the last fire (months), and month of last fire, was determined at each field site using burned area mapping.

The fire history of each study site was downloaded from the North Australian Fire Information Website (NAFI 2016) and processed from Landsat imagery (US Geological Survey 2016) at a spatial resolution of $30 \mathrm{~m}$ for 2006 through 2014. Data were sourced from Landsat 5 Thematic Mapper (2006), Landsat 7 Enhanced Thematic Mapper Plus (2007 through 2012), and Landsat 8 Operational Land Imager (2013 through 2014) imagery.

At least one satellite image per month was selected between April and December. No fires were recorded in the months January to March. To account for cloud cover, pre-processing of the Landsat images was performed with the software ENVI version 5.2 (Exelis Visual Information Solutions 2014) and involved radiometric calibration, converting digital numbers to reflectance, and atmospheric correction, using the dark pixel subtraction.

Object Based Image Analysis in eCognition Developer 8.7 (Trimble 2011) was used to classify burned areas, first segmenting the image into unclassified objects based on a measure of spectral properties, shape, size, texture, and context and then assigning each object as either "Burned" or "Unburned," based on predetermined criteria and complemented by thorough manual on-screen editing.

\section{Study species}

Sorghum stipoideum is an annual native spear grass species endemic to tropical northern Australia (north Western Australia and Northern Territory; Andrew and Mott 1983) and dominates lighter sandy soils of the region (Vigilante and Bowman 2004). Sorghum spp. seed germination is induced by rainfall at the beginning of the wet season. Seedlings are thought to emerge after rainfall exceeding $35 \mathrm{~mm}$ (Garnett and Williamson 2010), which is usually in October or November (Andrew and Mott 1983). More than half of the viable seeds available typically germinate after the first rainfall. The following cohorts germinate with successive rainfall events over the next month or so (Andrew and Mott 1983). S. stipoideum exists in a mosaic of low and high density patches across the landscape (Andrew 1986a). Typically, Sorghum stipoideum only had one tiller per plant with only one terminal inflorescence (Wheeler 1992). Sorghum stipoideum forms monodominant stands at densities of up to $200 \mathrm{~m}^{-2}$ (Andrew and Mott 1983). S. stipoideum growth and reproduction is complete by the end of the wet season (end of March) when seed fall occurs and plants begin to senesce (Andrew and Mott 1983, Cook and Andrew 1991). 


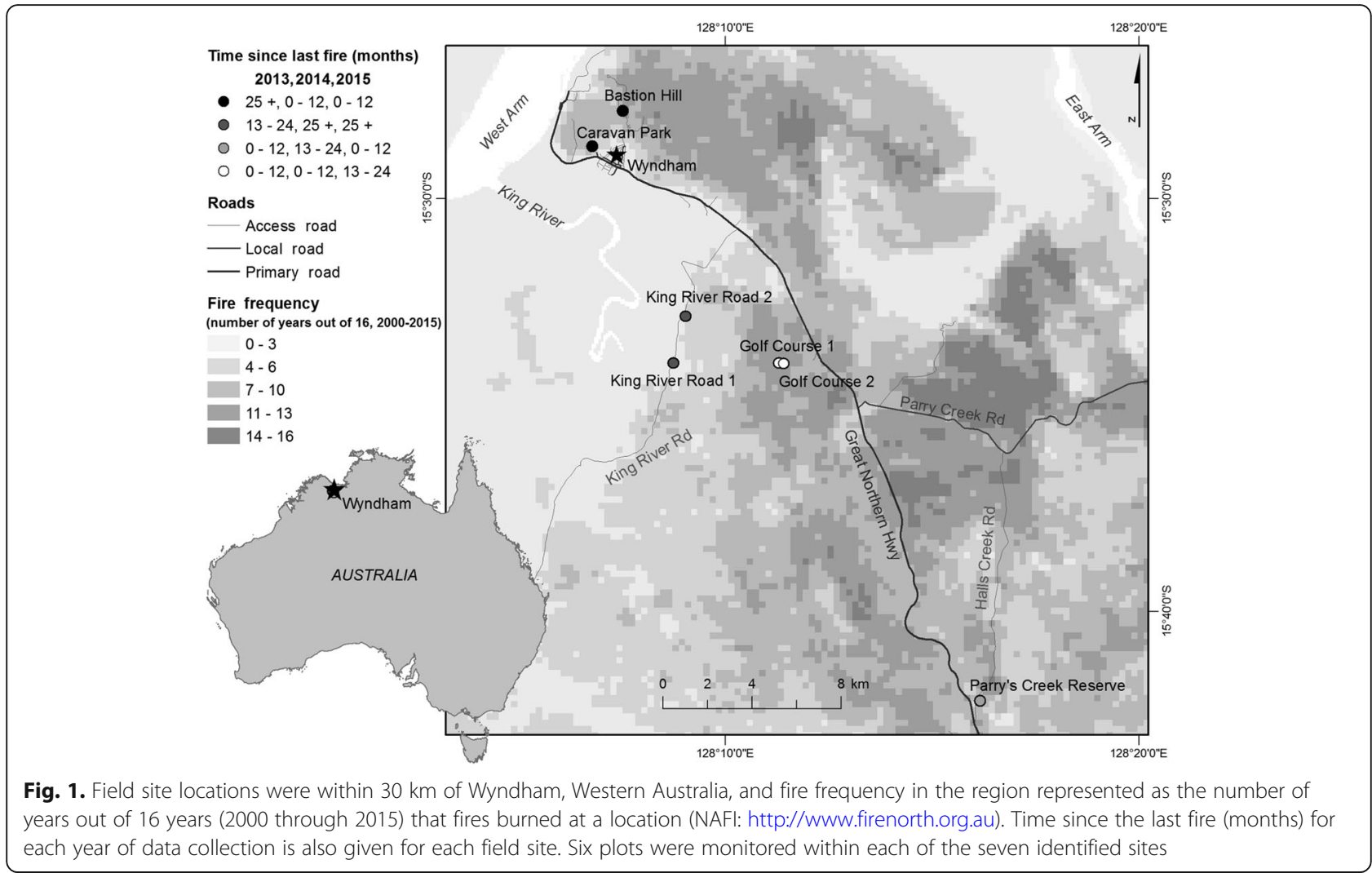

\section{Plant fecundity and density}

We monitored seeding S. stipoideum plants at five Gouldian finch breeding sites from February through March in three consecutive years, 2013 through 2015. We measured plant fecundity and density in $15 \mathrm{~m} \times$ $15 \mathrm{~m}$ plots. Three sites had six plots each, and two sites (Golf Course and King River study sites) had 12 plots each (six in each of two fire histories; Fig. 1). We randomly placed plots in S. stipoideum stands at each site, and laid out three permanent $1 \mathrm{~m} \times 1 \mathrm{~m}$ quadrats in each plot at $3 \mathrm{~m}$ intervals, along a $12 \mathrm{~m}$ transect along the diagonal of the plot. In the second and third years, quadrats were placed on a new transect parallel to the diagonal. In each quadrat, we counted S. stipoideum plants and randomly selected five plants for further measurement, including height $(\mathrm{cm})$, number of inflorescences per reproductive tiller, and florets per inflorescence (each floret is a precursor for one seed) (Andrew and Mott 1983). We used mean numbers of seeds per plant and mean number of plants per plot to derive estimates of seed density per $\mathrm{m}^{2}$.

\section{Field fire experiment}

Experimental burns were conducted at the abandoned Wyndham Golf Course in 2014 to examine the effect of fire season on density and fecundity of $S$. stipoideum plants. The experimental burns consisted of four treatments:
1) A very early dry season burn treatment (scorch height $<1 \mathrm{~m}$, low fire intensity) on 2 May

2) An early to mid dry season burn treatment (scorch height 2 to $3 \mathrm{~m}$, moderate intensity) on 26 June

3) An early wet season burn treatment after S. stipoideum seedling emergence (scorch height 2 to $3 \mathrm{~m}$, moderate intensity) on 18 December

4) A control (unburned and protected from wildfire by a fire break)

Very early dry season burns in May, approximating patchy burning for finch habitat management, were of low intensity and resulted in only partial consumption of leaf litter and ground layer vegetation. Early to mid dry season burns conducted in late June, and approximating early wildfires in the region, resulted in moderate intensity fires with complete consumption of ground layer vegetation and greater scorch height than very early burns. The early wet season burn treatment was included to assess impacts of management or lightning ignited fires that can affect Sorghum spp. seedlings post germination (Lonsdale et al. 1998). Early wet season burns were of moderate intensity. High intensity late dry season burns (Jul to Nov), representing late wildfire conditions, could not be conducted experimentally because of total fire bans during this season.

Experimental plots $(10 \mathrm{~m} \times 10 \mathrm{~m})$ were located within six experimental blocks $(16 \mathrm{~m} \times 55 \mathrm{~m})$, each block 
containing one replicate of each burn treatment. Burn treatments were randomly assigned to the four plots within each block. A $3 \mathrm{~m}$ fire break around each experimental block protected it from external wildfire and experimental burns. Fire breaks were created by cutting Sorghum spp. during the wet season (February) and then burning the breaks once the Sorghum spp. had dried (March). Experimental plots were ignited on the downwind edge using a drip torch prior to the upwind edge to provide a fire break of $>2 \mathrm{~m}$. Fire intensity was estimated using standard indices for northern Australian savannas based on scorch heights (Russell-Smith and Edwards 2006).

\section{Statistical analysis}

\section{Fire frequency, time since last fire, and timing of fire}

We examined the effects of fire frequency (number of years burned out of the previous nine), time since last fire (months), and fire season (month of fire) on all response variables (plant density, plant seed density, seed density) using generalized linear mixed models (GLMM). We specified a negative binomial distribution and log-link function, and ran models using $\mathrm{R}$ statistical software version 3.5.0 ( $\mathrm{R}$ Core Team 2018) and the lme4 package (Bates et al. 2015). Fire frequency, time since last fire, and timing of last fire were included as fixed effects. We allowed for non-linear trends by including these variables as either quadratic or cubic polynomial terms, and included site and year as random effects. We conducted analyses at the plot scale and accounted for differences in sampling effort by including offset terms for number of quadrats and plants sampled. We used an informationtheoretic approach to identify the best models (Grueber et al. 2011) according to AICc (Akaike information criterion corrected for small sample size) and retained only highly influential variables with relative variable importance $\geq 0.73$ (equivalent to an AICc difference of 2 , widely used to assess a "clear" effect: Richards 2005; R package MuMIn: Barton 2016).

\section{Effect of timing of experimental fires on seed abundance}

The effect of the experimental fire treatments in 2014 (four levels: control or no fire, early dry season, mid dry season, and wet season) on each of the response variablesplant density (plants $\mathrm{m}^{-2}$ ), plant seed density (seeds plant ${ }^{-1}$ ), and seed density (seeds $\mathrm{m}^{-2}$ ) were simultaneously examined using multivariate restricted maximum likelihood (REML) mixed models (Quinn and Keough 2002). REML models provide efficient estimates of treatment effects in unbalanced designs with more than one source of error. We specified fire treatment as a fixed effect and experimental block as a random effect in the model. We checked the model for homogeneity of variances and transformed data using either $\log _{10}$ (plant density, seed density) or ln (plant seed density). All REML analyses were conducted using GenStat version 17 (VSN International 2014).

\section{Results}

Plant density (plants $\mathrm{m}^{-2}$ ) was greatest after very early (April) or very late (September) dry season fires (Fig. 2a). Plant density was lowest following high intensity late dry season fires (August; Fig. 2a). There was no significant plant density response to fire frequency or time since last fire. The number of seeds per plant peaked at $\sim 40$ months since last fire (Fig. 2b). Seeds per plant did not differ significantly with fire frequency or month of the most recent fire (Fig. 2b). Seed density (seeds $\mathrm{m}^{-2}$ ) was significantly influenced by month of last fire (Fig. 2c). Maximum seed
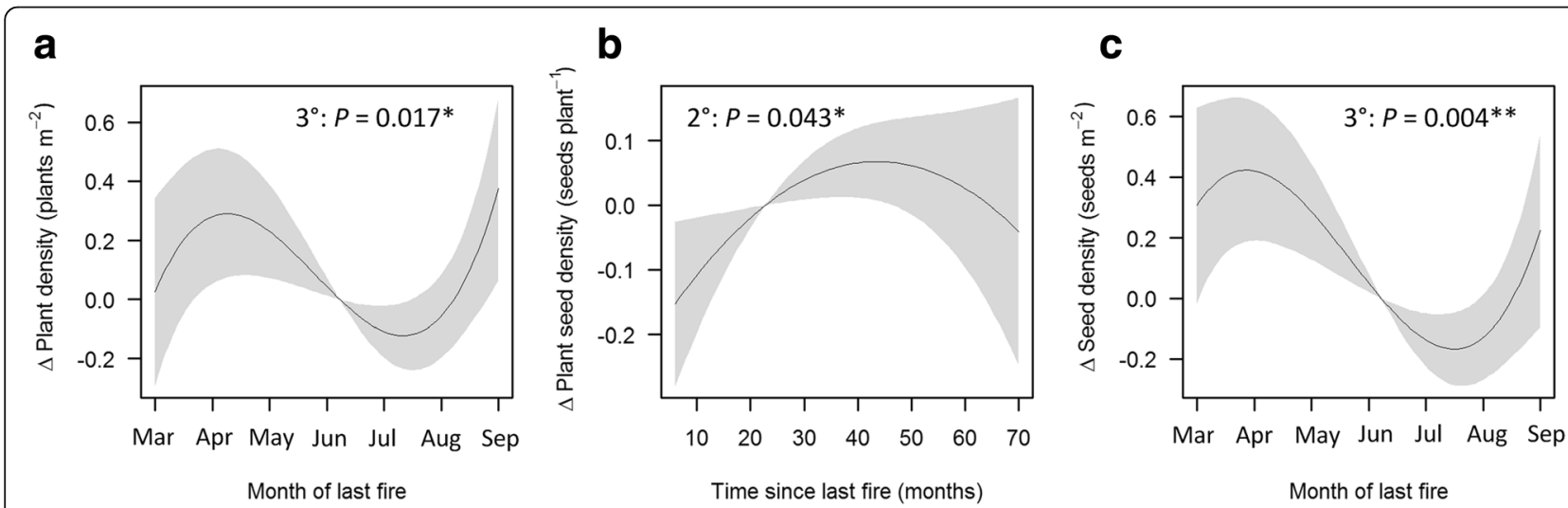

Fig. 2. The change $(\Delta)$ in response variables (plant density, plant seed density, and seed density) shown for highly influential predictor variables, i.e., month of last fire $(\mathbf{a}, \mathbf{c})$, and time since last fire (b). Relationships are displayed as contrast plots of fixed effects, with the mean value of the response variable as a reference point for change. In this way, random effects drop out of the model, which allows estimation of confidence intervals. The black line is model fit and the grey band represents $95 \%$ confidence interval. $P$-values for response variables included as polynomial terms $\left(2^{\circ}=\right.$ quadratic, $3^{\circ}=$ cubic) are shown with significance levels $\left({ }^{*}=0.01,^{*}=0.05\right)$. Plant density, plant seed density, and seed density data were collected from all Wyndham, Western Australia, sites (Bastion Hill, Caravan Park, King River Road 1 and 2, Golf Course 1 and 2, and Parry Creek Reserve) during Sorghum spp. seed set in March and April of 2013, 2014 , and 2015. 


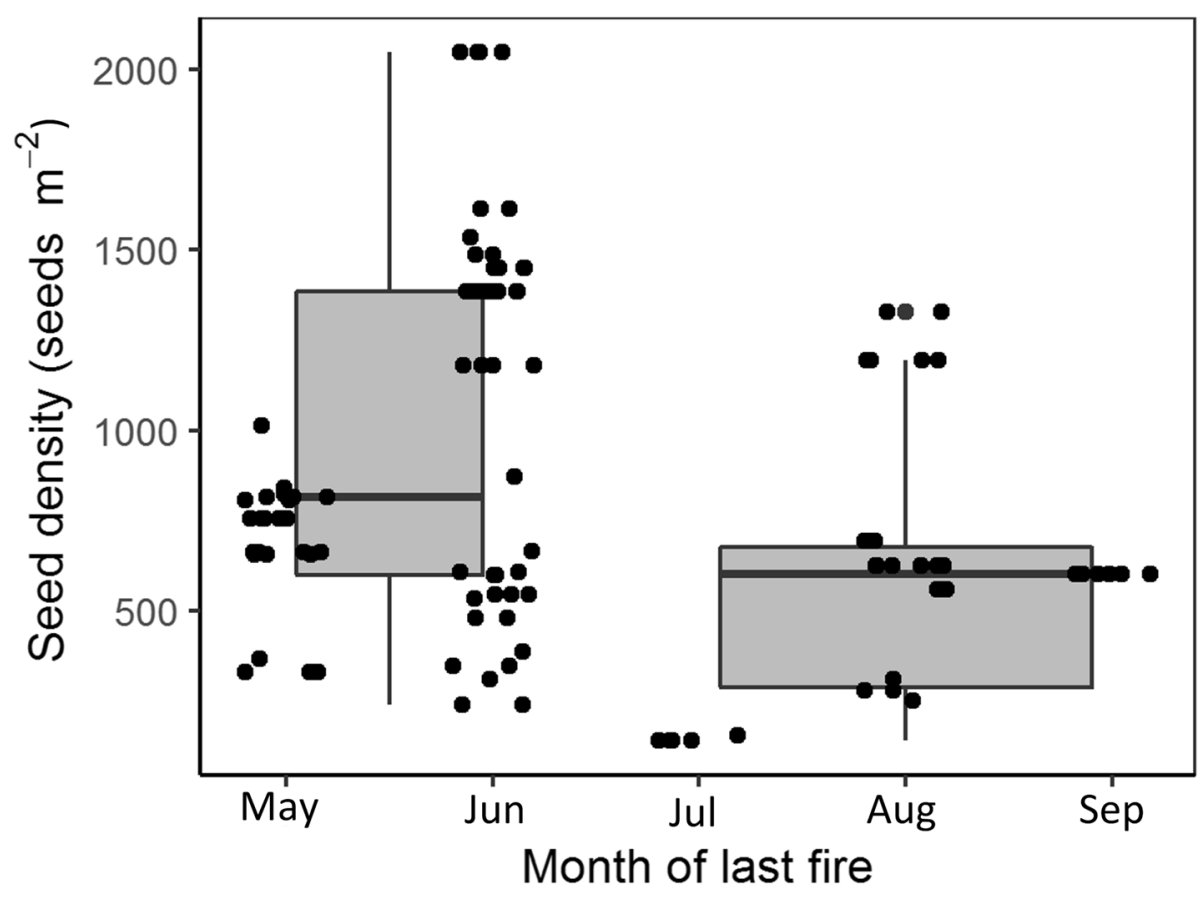

Fig. 3. Observed and model (GLMM) fitted values of Sorghum stipoideum seed density (seeds $\mathrm{m}^{-2}$ ) against month of last fire. Observed values are represented by dots, and fitted values are represented in a boxplot showing median (thick line), upper and lower quartiles (box), minimum and maximum values (whiskers) for early (before month 6) versus late dry season (after month 6) fires. Plant density, plant seed density, and seed density data were collected from all Wyndham, Western Australia, sites (Bastion Hill, Caravan Park, King River Road 1 and 2, Golf Course 1 and 2, and Parry Creek Reserve) at monthly intervals from May through September in 2013, 2014, and 2015.

density resulted from April (very early dry season) and September fires (very late dry season), while minimum seed density occurred following August (late dry season) fires (Fig. 2c), representing a $25 \%$ reduction in seed density ( $\sim 800$ to 600 seeds $\mathrm{m}^{-2}$; Fig. 3). There was no significant seed density response to fire frequency or time since last fire response (Fig. 2c).

Overall, there was a significant impact of experimental burn treatments $\left(F_{9,23.6}=19.36, P<0.001\right)$ on the response variables (plant density, seed density, and plant seed density); plant density was most significantly affected (Table 1), with the mid dry season (June) fires resulting in highest plant density. Wet season burns had the biggest negative effect on Sorghum, reducing plant density by $\sim 95 \%$ from 25 plants $\mathrm{m}^{-2}$ down to only 1.15 plants $\mathrm{m}^{-2}$ (Table 1). Although plants burned in the mid dry season produced less seed than the other treatments, there was no overall effect of the season of experimental burns on the numbers of seeds produced per plant. Because season of burn treatments affected plant density, the overall abundance of seeds (seeds $\mathrm{m}^{-2}$ ) was significantly affected, with greatest seed abundance associated with early dry season fire, and the least seed associated with the wet season fire (Table 1).

\section{Discussion}

Both experimental and observational results in this study revealed fire seasonal impacts on Sorghum spp. seed

Table 1 Mean and standard error of all response variables (plant density, plant seed density, and seed density). Multivariate restricted maximum likelihood (REML) linear mixed model analysis results for response variables, with treatment (four levels; early dry, mid dry, control, and wet) as fixed effects and block as a random effect. Bold type face indicates a significant $P$-value $(P=<0.05)$. Data from the abandoned Wyndham, Western Australia, Golf Course site collected 2 May 2014 (Early fire), 26 June 2014 (Mid dry season fire), 18 December 2014 (Wet season fire), and March 2015 (density responses).

\begin{tabular}{|c|c|c|c|c|c|c|c|}
\hline \multirow[t]{2}{*}{ Response variable } & \multicolumn{4}{|l|}{ Mean \pm SE } & \multicolumn{3}{|c|}{ ANOVA results } \\
\hline & Early & Mid dry & Wet & Control & $\mathrm{df}$ & $F$ & $P$ \\
\hline Plant density (plants $\mathrm{m}^{-2}$ ) & $19.23 \pm 1.23$ & $24.99 \pm 1.23$ & $1.15 \pm 1.23$ & $12.23 \pm 1.23$ & 3,15 & 49.47 & $<0.001$ \\
\hline Plant seed density (seeds plant ${ }^{-1}$ ) & $13.2 \pm 1.21$ & $10.5 \pm 1.21$ & $17.81 \pm 1.27$ & $12.4 \pm 1.21$ & $3,10.6$ & 1.23 & 0.345 \\
\hline Seed density (seeds $\mathrm{m}^{-2}$ ) & $225.42 \pm 1.21$ & $169.82 \pm 1.21$ & $35.48 \pm 1.28$ & $135.52 \pm 1.21$ & $3,10.7$ & 11.97 & $<0.001$ \\
\hline
\end{tabular}


bank density that influenced plant and seed density during the following year. Late dry season fires reduced plant and seed density at Gouldian finch breeding sites relative to sites that had experienced early dry season fires. Presumably, reduced Sorghum spp. density resulted from seed kill during medium to high intensity fires in the previous year (Scott et al. 2010). In contrast, we found no evidence of a fire frequency effect on Sorghum spp. seed production, and only a marginal influence of time since fire on seed numbers produced per plant. Lack of a time since fire or a fire frequency effect on Sorghum spp. seed density appears to contradict previous studies that associate frequent fires with high density Sorghum spp. populations (Russell-Smith et al. 2002, Russell-Smith et al. 2003, Scott et al. 2010). However, a lack of a fire frequency or time since fire effect on Sorghum spp. seed production in this study is consistent with the lack of an influence of fire on the phenology of seed set in Sorghum spp. (Weier et al. 2018).

Time since last fire influenced seed set per plant but not the overall density of plants and seeds. Consistent with our hypothesis, seed set increased with increasing time since fire up to a threshold of $\sim 40$ to 45 months and then declined. Plant growth is often stimulated by recent fire as soil nutrients are often enriched due to nitrogen mineralization and fixation with some fires (Gibson 2009); increases in inorganic nitrogen were demonstrated at our study sites following fire (Weier et al. 2017). However, fire can enhance Sorghum spp. seedling emergence and survival by removing leaf litter, reducing seed barriers, and reducing competition for light and resources as happened in this and in other studies (Hoare et al. 1980, Andrew and Mott 1983, Scott et al. 2010). Russell-Smith et al. (2003) found that S. stipoideum density decreased initially following fire, but populations recovered after 1 yr. Long unburned Sorghum spp. populations $(>10 \mathrm{yr})$ can also decline substantially (Russell-Smith et al. 2003). We did not find effects of time since fire on Sorghum spp. population and seed density in this study, which is likely related to the low productivity, rocky habitat in which Gouldian finches breed. Rocky substrates characteristic of finch breeding habitat may partially buffer seed banks from fire impacts, lessening impacts on seed banks in the first few years following fire events. Sparse woody vegetation cover on skeletal rocky soils at these breeding sites (tree basal area $1.8 \mathrm{~m}^{2} \mathrm{ha}^{-1}$, tree canopy cover $14.7 \%$, shrub canopy cover 1.7\%; I.J. Radford, Department of Biodiversity, Conservation and Attractions, Kununurra, Western Australia, Australia, unpublished data) may result in minimal competition up to $6 \mathrm{yr}$ post fire, before competition with Sorghum spp. plants would influence seed production (Russell-Smith et al. 2003, Scott et al. 2009,
Radford and Fairman 2015). Longer post fire intervals may also be required to allow greater perennial grass development (Dostine et al. 2001, Dostine and Franklin 2002) for competition with Sorghum spp. to occur. Under current, relatively frequent fire regimes in the context of Gouldian finch breeding habitat, it is therefore unlikely that changes in time since fire have had an appreciable impact on threatened finches.

Fire season was the most important fire regime attribute for Sorghum spp. that we identified here. The seasonal timing and resulting severity of a fire can affect the Sorghum spp. seed bank in several ways. Fires become more intense during the progress of the dry season (Byram 1959, Felderhof and Gillieson 2006). Our study demonstrated that late dry season fires resulted in lower Sorghum spp. plant densities compared with early dry season fires, likely because fire affects seed survival at or near the soil surface where many seeds disperse. However, lower Sorghum spp. plant density resulting from very early, patchy dry season fires (both natural and experimental plots) highlights another fire related mechanism affecting Sorghum spp. plant and seed density. As also found by Scott et al. (2010), very low intensity early dry season fires fail to remove all litter and herbaceous material from the soil surface. This results in a partial barrier and shading of the seed bank, and in lower S. stipoideum seed and plant density than after more intense dry season fires and experimental burns that consume all ground layer organic material. Under very low intensity fires, there is therefore an inhibitory effect on Sorghum spp. plant and seed density (Hoare et al. 1980, Andrew and Mott 1983, Scott et al. 2010). Despite very low and very high intensity fire reducing Sorghum spp. seed and plant density, seed density was only reduced by $\sim 25 \%$ (Fig. 3). This reduction is probably insufficient to limit breeding finches at the start of the dry season when seeds are still abundant at the soil surface (Weier et al. 2018). However, a reduction from median seed densities of 800 seeds $\mathrm{m}^{-2}$ down to 600 seeds $\mathrm{m}^{-2}$ may constitute a limiting factor for Gouldian finches in the late dry season when finches are under increasing stress (Maute $e t$ al. 2013, Legge et al. 2015) and seeds at the soil surface are increasingly sparse (Weier et al. 2018). Although previous research has shown that combined bird and mammal seed predation has negligible impacts on $S$. intrans seed numbers in Northern Territory savannas, harvester ants of the genus Meranoplus, Smith 1854, species can deplete Sorghum spp. seed banks by $\sim 60 \%$ toward the end of the dry season (Andrew 1986b). In this context, a $25 \%$ decline in seed density or availability caused by high or very low fire intensity may have repercussions for the duration and severity of critical late dry season food shortage periods (Dostine et al. 2001, Legge et al. 2015). 
Although late dry season fire reduced the density of annual Sorghum spp. plants to some extent, seed production per plant can partially compensate under reduced plant density and competition (Watkinson et al. 1989). Andrew (1986a) found that S. intrans plants had a higher fecundity in sparse stands compared to dense stands. Similarly, we found that as S. stipoideum density increased, the plants produced less seed and vice versa, although this response was only marginally significant. However, plant density and density-dependent fecundity mostly counteract each other, resulting in higher abundance of seeds after early dry season fires and, at the same sites, with higher plant density. As discussed above, seed abundance was lowest at sites burned late in the dry season irrespective of plant density.

As found previously (Lonsdale et al. 1998, Williams and Lane 1999), experimental wet season burns resulted in strongly negative impacts on annual Sorghum spp. seed bank density and resulting plant density the following year. Lonsdale et al. (1998) reported that wet season burns reduced the density of annual Sorghum brachypodum Lazarides species 10-fold, to an average of only 2 plants $\mathrm{m}^{-2}$. Our results are consistent with this, with plant density declining from 12.2 to 1.2 plants $\mathrm{m}^{-2}$ after a wet season fire. Unlike dry season fire impacts on $S$. stipoideum plant and seed density, impacts of early wet season fires result from fire related mortality of emergent seedlings, rather than seeds, which emerge following the first rains. Due to the relative sensitivity of Sorghum spp. seedlings to fire, relative to seed banks, wet season fire has the potential to completely remove Sorghum species from sites if extensively burned at this time (Smith 1960, Stocker and Sturtz 1966). Wet season fires are relatively rare and, if they do occur, are likely to be patchy due to high humidity and high moisture content of the senescent fuel. Wet season fires do not affect extensive areas of savannas generally (Russell-Smith et al. 2013) or Gouldian finch breeding habitat in particular. However, wet season prescribed burning may be implemented as part of a burning program, and has been advocated as a Sorghum spp. fuel management tool in some savanna circumstances (Williams and Lane 1999). Given the dependence of Gouldian finches on Sorghum spp. seed, particularly during the breeding season immediately after the wet season, extensive burning during this period would be inappropriate in Gouldian finch breeding habitat.

\section{Conclusions}

On average, $60 \%$ of the Wyndham region was burned annually and $>50 \%$ was burnt 5 to 6 times within nine years (Weier et al. 2016). Considering the relatively limited effect that the frequency of fire has on the density, fecundity, and seed abundance of annual Sorghum spp., it is unlikely that the current frequent fire regime will cause an appreciable impact or limitation on S. stipoideum seed availability to Gouldian finches during the breeding period (March to July; Weier et al. 2018). Lack of an apparent seed density limitation effect of fire during the breeding period means that breeding site choice is more likely determined by fire effects on seed nutritional value (Weier et al. 2017) than on the total number of available seeds. Early dry season fires will be most beneficial in terms of maximizing Sorghum spp. seed abundance and availability through the breeding and dry season. Lower frequency of early dry season fires was found to maximize nutritional content of Sorghum spp. seeds available to Gouldian finches (Weier et al. 2017) and likely influenced choice of breeding sites (Weier et al. 2016). Studies of breeding success in Gouldian finches also highlighted the influence of regional fire size and fire number in determining breeding success. More successful breeding occurred in years with multiple small fires than during years of a few large-scale fires (Weier et al. 2016). Greater breeding success with multiple small fires supports a patch "mosaic" burning approach to fire management of Gouldian finch breeding habitat, which is promoted by low fire intensity, early dry season burning. Such a regime would promote and maintain key resources for finches (e.g., food, cover, tree hollows) across savanna landscapes of northern Australia (Russell-Smith et al. 2013, Legge et al. 2015, Radford et al. 2015). Multiple small patchy early dry season fires will benefit Gouldian finches by increasing soil nutrient flushes resulting in increases in seed quality (Weier et al. 2017), as well as Sorghum spp. seed density and persistence. Patchy early dry season fires may also allow for greater development of mature, seeding perennial grasses as wet season seed resources for finches (Dostine et al. 2001). Previous studies have highlighted food shortages of perennial grass seeds under frequent fire regimes, especially during the late dry and the wet seasons (Dostine et al. 2001, Maute et al. 2013, Legge et al. 2015), although this is yet to be explicitly demonstrated. Future work into finch spatial movements and landscape resource use during putative food shortage periods will be necessary to fully unravel key ecological limitations for this tiny threatened grass finch.

\footnotetext{
Acknowledgements

We acknowledge and thank Dr. S. Pryke, M. Fidler, and the Save the Gouldian Fund for providing access to resources at the Wyndham research station. We thank the Balanggarra Aboriginal Corporation for access to their native title lands. We also thank R. Fairman; R. Clarke; T. Grounds; the Balanggarra Rangers; and the Department of Biodiversity, Conservation and Attractions for assistance and equipment with managing prescribed burns. We are grateful to I. Leiper who assisted with compiling Fig. 1. L.-A. Woolley was supported by the Australian Research Council (LP150100615) and the Australian Government's National Environmental Science Program through the Threatened Species Recovery Hub.
} 


\section{Funding}

This project was supported by the Biodiversity Fund, Commonwealth of Australia, as represented by the Department of Sustainability, Environment, Water, Population and Communities, and the Science Division, Department of Environment and Conservation (Project number: LSP-944229-932).

\section{Availability of data and supporting materials section}

Please contact authors for data requests.

\section{Authors' contributions}

AW designed and planned the study, carried out the ecological field work, undertook analyses, and wrote the manuscript. IR helped in design of study, some of the field studies, and with the writing of the manuscript. LW undertook statistical modeling analyses and write-up of methods and results. ML helped with design, statistical modeling analyses, and write-up of the study.

\section{Ethics approval and consent to participate}

Not applicable.

\section{Consent for publication}

Not applicable.

\section{Competing interests}

The authors declare they have no competing interests.

\section{Publisher's Note}

Springer Nature remains neutral with regard to jurisdictional claims in published maps and institutional affiliations.

\section{Author details}

${ }^{1}$ Research Institute for the Environment and Livelihoods, Charles Darwin University, Darwin, Northern Territory 0909, Australia. ${ }^{2}$ Department of Biodiversity, Conservation and Attractions, Lot 248 Ivanhoe Road, Kununurra, Western Australia 6743, Australia. ${ }^{3}$ NESP Threatened Species Recovery Hub, Charles Darwin University, Casuarina, Northern Territory 0909, Australia. ${ }^{4}$ School of Life Sciences, University of KwaZulu-Natal, P/Bag X01, Scottsville 3209, South Africa.

Received: 24 August 2018 Accepted: 25 October 2018

Published online: 27 December 2018

\section{References}

Andrew, M. 1986. Population dynamics of the tropical annual grass Sorghum intrans in relation to local patchiness in its abundance. Australian Journal of Ecology 11: 209-217 https://doi.org/10.1111/j.1442-9993.1986.tb01393.x.

Andrew, M. 1986. Granivory of the annual grass Sorghum intrans by the harvestor ant Meranoplus sp. in tropical Australia. Biotropica 18: 344-349 https://doi. org/10.2307/2388578.

Andrew, M.H., and J.J. Mott. 1983. Annuals with transient seed banks: The population biology of indigenous Sorghum species of tropical north-West Australia. Australian Journal of Ecology 8: 265-276.

Barton, K. 2016. MuMln: Multi-Model Inference. R package version 1 (15): 6 https:// CRAN.R-project.org/package=MuMIn. Accessed 15 Aug 2018.

Bates, D., M. Mächler, B. Bolker, and S. Walker. 2015. Fitting linear mixed-effects models using Ime4. Journal of Statistical Software 67: 1-48 https://doi.org/10. 18637/jss.v067.i01.

Blakers, M., S.J.J.F. Davies, and P.N. Reilly. 1984. The atlas of Australian birds. Melbourne, Australia: Melbourne University Press.

Brazill-Boast, J., J.K. Dessmann, G.T.O. Davies, S.R. Pryke, and S.C. Griffith. 2011. Selection of breeding habitat by the endangered Gouldian finch (Erythrura gouldiae) at two spatial scales. Emu 111: 304-311 https://doi.org/10.1071/mu10064.

Brazill-Boast, J., S.R. Pryke, and S.C. Griffith. 2013. Provisioning habitat with customdesigned nest-boxes increases reproductive success in an endangered finch. Austral Ecology 38: 405-412 https://doi.org/10.1111/j.1442-9993.2012.02424.x.

Byram, G.M. 1959. Combustion of forest fuels. In Forest fire: Control and use, ed. K. P. Davis, 61-89. New York, New York, USA: McGraw Hill.

Cook, G., and M. Andrew. 1991. The nutrient capital of indigenous Sorghum species and other understorey components of savannas in North-Western Australia. Australian Journal of Ecology 16: 375-384 https://doi.org/10.1111/j. 1442-9993.1991.tb01065.x
Crowley, G., and S. Garnett. 1999. Seeds of the annual grasses Schizachyrium spp. as a food resource for tropical granivorous birds. Australian Journal of Ecology 24: 208-220 https://doi.org/10.1046/j.1442-9993.1999.00964.x.

Department of the Environment. 2016. Erythrura gouldiae in species profile and threats database. <http://www.environment.gov.au/sprat>. Accessed 8 June 2016.

Dostine, P.L., and D.C. Franklin. 2002. A comparison of the diet of three finch species in the Yinberrie Hills area, Northern Territory. Emu 102: 159-164 https://doi.org/10.1071/MU01034.

Dostine, P.L., G.C. Johnson, D.C. Franklin, Y. Zhang, and C. Hempel. 2001. Seasonal use of savanna landscapes by the Gouldian finch, Erythrura gouldiae, in the Yinberrie Hills area, Northern Territory. Wildlife Research 28: 445-458 https:// doi.org/10.1071/WR00049.

Exelis Visual Information Solutions. 2014. ENVI 5.2. Exelis visual information solutions, Boulder, Colorado, USA.

Felderhof, L., and D. Gillieson. 2006. Comparison of fire patterns and fire frequency in two tropical savanna bioregions. Austral Ecology 31: 736-746 https://doi.org/10.1111/j.1442-9993.2006.01645.x.

Garnett, S.T., and G. Williamson. 2010. Spatial and temporal variation in precipitation at the start of the rainy season in tropical Australia. Rangeland Journal 32: 215-226 https://doi.org/10.1071/RJ09083.

Gibson, D.J. 2009. Grasses and grassland ecology. New York, New York, USA: Oxford University Press Inc.

Grueber, C.E., S. Nakagawa, R.J. Laws, and I.G. Jamieson. 2011. Multimodel inference in ecology and evolution: Challenges and solutions. Journal of Evolutionary Biology 24: 699-711 https://doi.org/10.1111/j.1420-9101.2010. 02210.x.

Hoare, J., R. Hooper, N. Cheney, and K. Jacobsen. 1980. A report on the effects of fire in tall open forest and woodland with particular reference to fire management in Kakadu National Park in the Northern Territory. Canberra, Australia: Australian National Parks and Wildlife Service.

Legge, S., S. Garnett, K. Maute, J. Heathcote, S. Murphy, J.C. Woinarski, and L. Astheimer. 2015. A landscape-scale, applied fire management experiment promotes recovery of a population of the threatened Gouldian finch, Erythrura gouldiae, in Australia's tropical savannas. PLoS One 10: e0137997 https://doi.org/10.1371/journal.pone.0137997.

Lewis, M. 2007. Foraging responses of the endangered Gouldian finch to temporal differences in seed availability in northern Australian savanna grasslands. In Temporal dimensions of landscape ecology, ed. J. Bissonette and I. Storch, 218-235. Boston, Massachusetts, USA: Springer https://doi.org/10. 1007/978-0-387-45447-4_13.

Liedloff, A.C., M.B. Coughenour, J.A. Ludwig, and R. Dyer. 2001. Modelling the trade-off between fire and grazing in a tropical savanna landscape, northern Australia. Environment International 27: 173-180 https://doi.org/10.1016/ S0160-4120(01)00079-4.

Lonsdale, W.M., R.W. Braithwaite, A.M. Lane, and J. Farmer. 1998. Modelling the recovery of an annual savanna grass following a fire-induced crash. Australian Journal of Ecology 23: 509-513 https://doi.org/10.1111/j.1442-9993.1998. tb00761.x.

Maute, K.L., K. French, S. Legge, and L. Astheimer. 2013. Seasonal stress physiology and body condition differ among co-occurring tropical finch species. Journal of Comparative Physiology B 183: 1023-1037 https://doi.org/ 10.1007/s00360-013-0775-y.

Mott, J.J., and M.H. Andrew. 1985. The effect of fire on the population dynamics of native grasses in tropical savannas of north-West Australia. Proceedings of the Ecological Society of Australia 13: 231-239.

NAFI [North Australia and Rangelands Fire Information]. 2016. North Australia and rangelands fire information home page. <http://www.firenorth.org.au/>. Accessed 25 January 2016.

Pryke, S.R., L.B. Astheimer, S.C. Griffith, and W.A. Buttemer. 2012. Co-variation in life history traits: Differential effects of diet on condition, hormones, behaviour, and reproduction in genetic finch morphs. The American Naturalist 179: 375-390 https://doi.org/10.1086/664078.

Quinn, G.P., and M.J. Keough. 2002. Experimental design and data analysis for biologists. Cambridge, England, United Kingdom: Cambridge University Press. https://doi.org/10.1017/CBO9780511806384.

R Core Team. 2018. R: A language and environment for statistical computing. Vienna, Austria: R Foundation for Statistical Computing.

Radford, I.J., and R. Fairman. 2015. Fauna and vegetation responses to fire and invasion by toxic cane toads (Rhinella marina) in an obligate seeder dominated tropical savanna in the Kimberley, northern Australia. Wildlife Research 42: 302-314 https://doi.org/10.1071/WR14259. 
Radford, I.J., L.A. Gibson, B. Corey, K. Carnes, and R. Fairman. 2015. Influence of fire mosaics, habitat characteristics and cattle disturbance on mammals in fireprone savanna landscapes of the northern Kimberley. PLoS One 10: e0130721 https://doi.org/10.1371/journal.pone.0130721.

Reside, A.E., J. VanDerWal, A. Kutt, I. Watson, and S. Williams. 2012. Fire regime shifts affect bird species distributions. Diversity Distributions 18: 213-225 https://doi.org/10.1111/j.1472-4642.2011.00818.x.

Richards, S.A. 2005. Testing ecological theory using the information-theoretic approach: Examples and cautionary results. Ecology 86: 2805-2814 https:// doi.org/10.1890/05-0074.

Russell-Smith, J., G.D. Cook, P.M. Cooke, A.C. Edwards, M. Lendrum, C.P. Meyer, and P. J. Whitehead. 2013. Managing fire regimes in north Australian savannas: Applying aboriginal approaches to contemporary global problems. Frontiers in Ecology and the Environment 11: e55-e63 https://doi.org/10.1890/120251.

Russell-Smith, J., and A. Edwards. 2006. Seasonality and fire severity in savanna landscapes of northern Australia. International Journal of Wildland Fire 15: 541-550 https://doi.org/10.1071/WF05111.

Russell-Smith, J., P.G. Ryan, and D.C. Cheal. 2002. Fire regimes and the conservation of sandstone heath in monsoonal northern Australia: Frequency, interval, patchiness. Biological Conservation 104: 91-106 https:// doi.org/10.1016/S0006-3207(01)00157-4.

Russell-Smith, J., P.J. Whitehead, G.D. Cook, and J.L. Hoare. 2003. Response of Eucalyptus-dominated savanna to frequent fires: Lessons from Munmarlary, 1973 -1996. Ecological Monographs 73: 349-375 https://doi.org/10.1890/01-4021.

Scott, K.A., S.A. Setterfield, A.N. Andersen, and M.M. Douglas. 2009. Correlates of grass-species composition in a savanna woodland in northern Australia. Australian Journal of Botany 57: 10-17 https://doi.org/10.1071/BT08120.

Scott, K.A., S.A. Setterfield, M.M. Douglas, and A.N. Andersen. 2010. Environmental factors influencing the establishment, height and fecundity of the annual grass Sorghum intrans in an Australian tropical savanna. Journal ofTropical Ecology 26: 313-322 https://doi.org/10.1017/S0266467409990629.

Silvertown, J., and D. Charlesworth. 2001. Introduction to plant population biology. Malden, Massachusetts, USA: Blackwell Publishing.

Smith, E.L. 1960. Effects of burning and clipping at various times during the wet season on tropical tall grass range in northern Australia. Journal of Range Management 13: 197-203 https://doi.org/10.2307/3894952.

Stocker, G., and J. Sturtz. 1966. The use of fire to establish Townsville lucerne in the Northern Territory. Animal Production Science 6: 277-279 https://doi.org/ 10.1071/EA9660277

Tidemann, S.C. 1993. Management of a threatened species: The Gouldian finch example. Brisbane, Australia: Queensland Ornithological Society.

Tidemann, S.C. 1996. Causes of the decline of the Gouldian finch Erythrura gouldiae. Bird Conservation International 6: 49-62 https://doi.org/10.1017/ S0959270900001301.

Trimble. 2011. eCognition developer 8.7 user guide. Munich, Germany: Trimble Documentation.

US Geological Survey. 2016. Global visualization viewer. <http://glovis.usgs.gov>. Accessed 25 January 2016.

Vigilante, T., and D.M. Bowman. 2004. Effects of fire history on the structure and floristic composition of woody vegetation around Kalumburu, North Kimberley, Australia: A landscape-scale natural experiment. Australian Journal of Botany 52: 381-404 https://doi.org/10.1071/BT03156.

VSN International. 2014. GenStat for windows. Hemel Hempstead, England, United Kingdom: VSN International.

Watkinson, A.R., W.M. Lonsdale, and M.H. Andrew. 1989. Modelling the population dynamics of an annual plant Sorghum intrans in the wet-dry tropics. Journal of Ecology 77: 162-181 https://doi.org/10.2307/2260923.

Weier, A., I.J. Radford, S.M. Bellairs, and M.J. Lawes. 2018. Seed set in Sorghum stipoideum, and not fire, determines the timing of breeding by Gouldian finches (Erythrura gouldiae). Austral Ecology. https://doi.org/10.1111/aec.12662.

Weier, A., I.J. Radford, A. Manson, L.J. Durrans, and M.J. Lawes. 2017. Frequent fires reduce the nutritional quality of Sorghum stipoideum seed, a keystone food resource for the Gouldian finch (Erythrura gouldiae). Rangeland Journal 39: 105-112 https://doi.org/10.1071/RJ16124.

Weier, A., I.J. Radford, S.L.J. Oliviera, and M.J. Lawes. 2016. Recently and infrequently burnt breeding sites are favoured by threatened Gouldian finches (Erythrura gouldiae). International Journal of Wildland Fire 25: 1281-1290 https://doi.org/10. 1071/NF16105

Wheeler, J.R. 1992. Flora of the Kimberley region. Como, Western Australia, Australia: Western Australian Herbarium, Department of Conservation and Land Management.
Williams, R., and A. Lane. 1999. Wet season burning as a fuel management tool in wet-dry tropical savannas: Applications at ranger mine, Northern Territory, Australia, proceedings of VIlth international rangeland congress, Townsville 2, 972-977.

Woinarski, J., B. Mackey, H. Nix, and B. Traill. 2007. The nature of northern Australia: Its natural values, ecological processing and future prospects. Canberra, Australia: ANU Press.

Woinarski, J., J. Risler, and L. Kean. 2004. Response of vegetation and vertebrate fauna to 23 years of fire exclusion in a tropical Eucalyptus open forest, Northern Territory, Australia. Austral Ecology 29: 156-176 https://doi.org/10. 1111/j.1442-9993.2004.01333.x.

Woinarski, J.C.Z., and S. Legge. 2013. The impacts of fire on birds in Australia's tropical savannas. Emu 113: 319-352 https://doi.org/10.1071/MU12109.

\section{Submit your manuscript to a SpringerOpen ${ }^{\circ}$ journal and benefit from:}

- Convenient online submission

- Rigorous peer review

- Open access: articles freely available online

- High visibility within the field

- Retaining the copyright to your article

Submit your next manuscript at $\boldsymbol{\nabla}$ springeropen.com 